\title{
Keeping the Nazi Menace Out: George Lincoln Rockwell and the Border Control System in Australia and Britain in the Early 1960s
}

\author{
Evan Smith \\ College of Humanities, Arts and Social Sciences, Flinders University, Bedford Park, Adelaide, SA 5042, Australia;
} evan.smith@flinders.edu.au

Received: 21 August 2020; Accepted: 8 September 2020; Published: 11 September 2020

\begin{abstract}
In the early 1960s, the American Nazi Party leader George Lincoln Rockwell was invited by neo-Nazi groups in Australia and Britain to come to their respective countries. On both occasions, the minister for immigration in Australia and the home secretary in Britain sought to deny Rockwell entry to the country on the grounds that he was not conducive to the public good and threatened disorder. This was done using the border control and visa system that existed in both countries, which allowed the government to exclude from entry certain individuals that were proponents of extreme or "dangerous" political ideologies. In the post-war period, explicit neo-Nazism was seen as a dangerous ideology and was grounds for exclusion of foreigners, even though domestic political parties espousing the same ideology were allowed to exist. Rockwell never came to Australia, but illicitly entered Britain via Ireland in 1962 before being deported, which highlighted potential problems for the British controlling passage across the Irish Sea. Rockwell's exclusion and deportation also became a touchpoint for future debates in British politics about the denial of entry and deportation of political figures. This article reveals that the Australian and British governments, while allowing far-right organisations to lawfully exist in their countries, also sought to ban the entry of foreign actors who espoused similar politics. This was due to concerns about potential public disorder and violence, but also allowed both governments to portray white supremacism and racial violence as foreign to their own countries.
\end{abstract}

Keywords: George Lincoln Rockwell; Colin Jordan; American Nazi Party; Australian Nationalist Workers Party; National Socialist Movement; border control; deportation

\section{Introduction}

One of the tenets of modern liberal democracy in both Britain and Australia is the freedom of political association, although this freedom has not always been so straight forward in practice. Throughout the twentieth century, it was rare for a political organisation to be proscribed in either country and cases where the government sought to impede this have become infamous, such as the banning of the British Union of Fascists (BUF) during the Second World War or the dissolution of the Communist Party of Australia in the early 1950s. While the British and Australian governments have been reluctant to proscribe political groups in the domestic sphere, they have also seen a number of political ideologies on the right and left as "subversive" and "foreign" to the political landscape in both countries. These have included fascism, anarchism, communism, and anti-colonialism (to name a few). Concerned about the introduction of foreign political ideologies into domestic politics, both governments have sought to keep out individuals belonging to political organisations and campaigns that have been seen as political threats.

Since the establishment of the modern border control system in both countries at the turn of the twentieth century, Britain and Australia have used the system to prevent "undesirable" individuals 
from entering or deporting those found to be subversive and a non-citizen. Much of the literature on this has looked at how the border control system was used identify, monitor, reject and deport political activists on the left or involved in anti-colonial politics (Deery 2005; Ullrich 2011; Piccini 2016; Brückenhaus 2017); this article will look at two particular incidents when the British and Australian governments used the border control system to reject or deport a figure from the far right ${ }^{1}$.

In the early 1960s, the leader of the American Nazi Party, George Lincoln Rockwell, sought to enter both Australia and Britain. In the Australian case, the government publicly announced that it would not grant Rockwell a visa as his presence was not conducive to the public good. The following year, the British government took a similar stance, but Rockwell entered the country illegally and was subsequently deported. In both instances, Rockwell had been invited by neo-Nazi organisations in Australia and Britain ${ }^{2}$, which were allowed to legally operate as political groups (although arrests were made for party members involved in weapons offences) (Harcourt 1972, pp. 16-17; Jackson 2018, pp. 114-17). However, Rockwell, also a member of a legal political group in the United States, was denied entry for espousing similar politics to the domestic neo-Nazis in Australia and Britain. Both countries had also allowed numerous former members of the German National Socialists and the Italian fascists, as well as other wartime collaborators, into the country as migrants in the 1950s (Aarons 1989; Cesarani 1992; Persian 2017). This article will explore why Rockwell, as a controversial public figure, was denied entry into Australia and Britain in the early 1960s and describe the changing perception of fascism in the post-war period, as well as how the border control system operated as a filter on undesirable politics coming into the country.

\section{Post-War Fascism in Australia and Britain}

Both Australia and Britain had witnessed fascist movements during the inter-war period and the fascist groups that existed during those years were banned during the Second World War, with several key figures interned in both countries. In Britain, the end of the war saw several far-right groups emerge, with the most prominent being Oswald Mosley's Union Movement (UM) and the British People's Party (BPP). Mosley's UM essentially continued the programme of his British Union of Fascists from the inter-war period, while the BPP, which was staffed at the higher levels by several ex-BUF members, was a more explicitly national socialist organisation (Thurlow 1998, pp. 203-12; Renton 2000, p. 26). After anti-fascist opposition to the UM caused Mosley to go into self-imposed exile in Ireland in the early 1950s and the BPP wound up with the death of its major benefactor, Lord Tavistock, a few years later, a new generation of fascists emerged. These fascists were more influenced by the Imperial Fascist League's Arnold Leese than Mosley or the BPP's John Beckett (Macklin 2020, p. 68).

At the centre of this reorienting of British fascism towards Leese via the BPP was Colin Jordan. Jordan had been involved in the BPP while at Cambridge University in the late 1940s and then drifted into the orbit of Leese, eventually taking control of "Arnold Leese House" after his death, a building in West London out of which Jordan's various political organisations were based (Jackson 2018). In 1954, ex-BUF Director of Propaganda A.K. Chesterton established the League of Empire Loyalists (LEL) and Jordan was an early member of this group. On the surface, the LEL operated as a pressure group on the right of the Conservative Party, opposing decolonisation and Commonwealth immigration, but was also indulged in anti-Semitism dressed up as conspiracy theory. The LEL acted as a conveyor belt for most significant personalities of British fascism for the next twenty years and, alongside Chesterton and Jordan, saw leading figures such as John Tyndall, John Bean and Martin Webster pass through it, before the LEL became part of the National Front in 1967 (LeCras 2020).

By 1957, Jordan's explicit anti-Semitism had led him to part ways with Chesterton and the LEL and he set up the White Defence League (WDL) out of Arnold Leese House in Notting Hill. During the

\footnotetext{
The term "far right" is used in this article as a general term to describe illiberal, racist and fascist groups on the right. The term "neo-Nazi" is used in this article to describe the groups that were explicitly based on Hitler's Nazi Party.
} 
Notting Hill riots in the following year, the WDL attempted to harness racism against Commonwealth migrants into a fascist street movement (competing with Mosley's Union Movement over this) (Jackson 2018, pp. 81-91). However, the WDL remained tiny and, in 1960, it merged with John Bean's National Labour Party (also a split from the LEL) into the British National Party (BNP). Bean and Jordan clashed over leadership of the BNP and how explicit their Nazism should be, with Bean attempting to steer the party towards a fascism with a more British face, as opposed to Jordan's Hitler worship (Jackson 2018, pp. 91-100; Macklin 2020, pp. 270-76). In 1962, this division culminated in a split, with Jordan, followed by Tyndall, setting up the National Socialist Movement (NSM). It was the NSM that attempted to foster closer links with George Lincoln Rockwell's American Nazi Party (ANP) and help establish the World Union of National Socialists (WUNS).

The far right in Australia also went through a transitional period in the post-war era. The paramilitary New Guard and its political wing, the Centre Party, had already faded by the mid-1930s and the Australia First Movement (AFM) did not survive with the war, with several of its members interned. A number of small groups, such as the Australian Nationalist Movement and the White Australia League, were established with links to former AFM members, trying to eke out a political space to the right of Menzies's Liberal Party, in a time when anti-communism and defence of the "White Australia Policy" were bipartisan political positions (Moore 1995, p. 56). Frank Browne, a Sydney journalist who had previously been a candidate for Menzies's United Australia Party during the war, shifted further to the right and created the Australian Party after being released from jail in 1955. By 1959, Browne had met other neo-Nazis, such as Arthur Smith and Graeme Theo Royce, and formed the Australian Nationalist Workers Party (ANWP) (Henderson 2005). Royce and Smith made contact with Jordan in Britain and Rockwell in the United States and plugged into a global circuit of neo-Nazis, which grew in the 1960s.

George Lincoln Rockwell had been involved in conservative right circles in the second half of the 1950s before starting up the World Union of Free Enterprise National Socialists in March 1959, but by the end of the year, this had become the American Nazi Party (ANP). The Cold War saw the ANP campaign heavily against communism and racial desegregation, with Rockwell purporting that both were Jewish conspiracies (Simonelli 1999). Like the various groups of Colin Jordan and the Australian Nationalist Workers Party, the ANP was a tiny organisation that thrived on notoriety and public spectacles, alongside an enthusiasm for paramilitarism. Possibly due to the small stature of the ANP, Rockwell sought international connections from the very beginning. Alongside the strong relationship that he fostered with Jordan in Britain, he made contact with ex-Nazis and neo-Nazis in Europe, South America and South Africa (as well as Australia and New Zealand) (Jackson 2019).

\section{Border Control and the Vetting of Political Extremists}

Both Australia and Britain had implemented explicit restrictions on people entering the country, as either a migrant or a visitor, who were suspected of being involved in subversive, seditious or treasonous politics since the First World War.

In Australia, the War Precautions Act of 1914 permitted the registration of aliens, enforced by regulations in 1916, and was followed by two versions of the Unlawful Associations Act in 1916 and 1917, which allowed for the deportation of people born outside of Australia for being involved in subversive activities. Although the measures introduced during wartime were meant to be temporary, once the national security "genie" had been unleashed, it was very difficult for the peacetime governments that followed to put it back in the bottle. As Finnane and Kaladelfos (2019, p. 27) have written, the "earlier enactment of wartime restrictions, and the associated institutional creativity, consolidated the immigration regime as a central element of national defence."

In the inter-war period, the border control system was used to identify, monitor, reject and deport those deemed to be involved in subversive politics or political violence. In the 1920s and 1930s, efforts were made to deport socialists. In 1925, the amended Immigration Act was used in an attempt to expel Tom Walsh and Jack Johnson, who were both members of the Seamen's Union, which was overturned 
by the High Court (Nicholls 2007, pp. 58-61). In his history of the Communist Party of Australia, Macintyre (1999, p. 101) notes that several communists were not allowed into the country or were only allowed in under strict conditions. For example, Dora Montefiore, a member of the Communist Party of Great Britain, was "permitted to Australia in 1922 only after she surrendered her passport and promised not to engage in communist propaganda."

After the Second World War, potential migrants and visitors underwent significant political vetting, with the Australian Security Intelligence Organisation (ASIO) involved with the screening of migrants from post-war Europe. A particular emphasis was placed on those coming from Eastern Europe and countries with large national communist parties, such as Greece or Italy, as well as those coming from China after 1949. In the late 1950s, the Australian border control system was overhauled under the new Migration Act 1958, which explicitly allowed for the deportation of "violent" political activists. Freckelton (2015, p. 29) has written the Migration Act had little explicit instruction about the denial of entry, but instructions provided to immigration officials in the early 1960s reveals that entry permits for aliens (such as visitors from the United States) could be refused if considered not to be "of good character" 3 . As this article will show, George Lincoln Rockwell was certainly not thought of in this regard.

Until the 1970s, Britain distinguished between migrants and visitors from the Empire/ Commonwealth (deemed "British subjects") and those from elsewhere (deemed "aliens"). Although Britain had harboured a number of political exiles and activists for centuries, other politically undesirable aliens were refused entry or deported over the years (as all British subjects technically had the right of entry into the country, it was more difficult to prevent entry of dissidents from within the British Empire). The outbreak of the First World War led to legislation that excluded "enemy aliens" and the Aliens Restrictions (Amendment) Act 1919 kept many of the restrictions on former enemy aliens and other suspected subversives into peace time. After the Second World War, several pieces of legislation and government orders built upon the 1919 Act to refuse entry to and deport politically undesirable aliens. The Aliens Order 1953 gave the home secretary total discretion to refuse entry to alien visitors (including for political reasons) or to impose conditions upon their entry (such as involvement in political activity in Britain).

\section{Rockwell's Plan to Visit Australia}

In January 1961, several Australian newspapers reported on an invitation by the Australian Nationalist Workers Party for Rockwell to visit Australia in a few months' time. Before Rockwell could make an application for a visa, the minister for immigration, Alexander Downer, reportedly stated that Rockwell "would be most unwelcome in Australia if reports about him were true" (The Age, 31 January 1961). Downer pre-emptively shut down Rockwell's chance of obtaining a visa, but admitted that, at this stage, an application had not been made. A cablegram from the Australian Embassy in Washington indicated that Rockwell made a formal application in the week following the story being in the press ${ }^{4}$. Quoted in the Embassy's cablegram, Rockwell stated his intentions were to confer with members of the World Union of Free Enterprise National Socialists in Australia, naming Graeme Royce and Arthur Smith. While acknowledging that he would be meeting with these neo-Nazis in Sydney, he also declared: "I shall make no public speeches or interfere with the internal politics of Australia during my visit, other than to address private meetings of National Socialists in Australia and to advise our members".

Anticipating this application, internal archival documents indicate that the Australian government made it clear that if Rockwell was to apply for a visa, that it would be forwarded to the Department

3 Department of Immigration, Boarding Handbook, November 1960, paragraph 171.7, PP464/1 1, National Archives of Australia (hereafter NAA) (Perth).

4 Cablegram from Australian Embassy in Washington to the Department of External Affairs, 7 February 1961, A1209 1961/308, NAA (Canberra). 
of Immigration in Canberra and the Commonwealth Migration Officer for vetting and "discreet enquiries" ${ }^{5}$. ASIO was consulted by the Department of Immigration and the director-general of the security agency, Charles Spry, communicated, "I consider that there is a strong security objection to

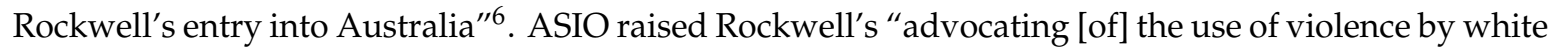
races to suppress the black races led by 'the scheming Jew'" as the reason for this security objection, with Spry referring to Rockwell's book In Hoc Signo Vinces. Apart from the statement to the media by Downer in late January, it was decided by the government that no press statement would be issued once the visa was refused to defuse publicity for Rockwell and the Australian neo-Nazis ${ }^{7}$.

While these machinations happened inside government, various groups around Australia reacted to Rockwell's proposed visit. The national secretary of the Returned Soldiers' League (RSL), Arthur Lee, sent a letter to the minister for immigration objecting to Rockwell's possible entry and enquiring whether the Australian equivalent of the American Nazi Party was under surveillance ${ }^{8}$. Harcourt (1972, p. 8) quotes Lee as stating that "should the government allow this man to enter Australia it will be opposed by every member of the RSL". An editorial in the Sydney Morning Herald (1 February 1961) congratulated Downer's decision to refuse a visa to Rockwell, saying that the decision "will be applauded by all" and stressed that " $[t]$ he simple point is that, eccentric or fanatic or plain publicity-hunter, this man is, by any decent standards, a political undesirable". The Communist Party of Australia's newspaper, Tribune (1 February 1961) reported that several trade unions also objected to Rockwell coming to the country, with the Queensland state secretary of the Australasian Meat Industry Employees' Union declaring, "It is disgusting to contemplate the prospect of Australian youth, who have no clear recollection of the horrors of fascism, having their minds bombarded with Nazi filth, including ... Jew-baiting, Red-baiting and white supremacy ..."

An editorial for the current affairs journal The Bulletin (8 February 1961) called the communist campaign against Rockwell entering the country as a "kind of double-think" and if political control of visitors was to be exercised, the journal suggested:

the people whom it would be necessary to exclude would not be the lunatic fringe, but those very Communist heroes who now come in and out of this country at will, the blood of their own countrymen on their hands and the desire to smash the democratic institutions of Australia in their minds.

Rockwell, on the other hand, was seen as "an empty, trouble-making nothing" with "no political significance". Believing that political control of visitors did democratic harm, The Bulletin suggested that Rockwell could be excluded as he had "a court record for public disorder and incitement to violence". Describing him as "a deliberate despoiler of the peace", the journal argued that "[w]e should not treat him as a political martyr, or as a political case at all, but as a public nuisance" and he could be prevented from coming to Australia like others with criminal records.

As the public denouncements mounted, it became clearer that first and foremost, the proposed visit from the leader of the American Nazi Party was a publicity stunt. If a visa was granted, this would have been an opportunity for the neo-Nazis in both countries to forge a closer relationship, but if the visa was denied, the Australian Nationalist Workers Party would benefit from the notoriety and the media interest. The Melbourne tabloid The Sun (6 February 1961) reported that the American Nazi Party was broke and wanted Royce to pay for Rockwell's travel to Australia, while Royce and Smith did not have the means to do so (Harcourt 1972, pp. 8-9; Henderson 2005, p. 82). The Sun alleged that Royce had led Rockwell to believe that the ANWP had about 750 followers and a mailing list of 4000, while the real number, it was reported, was only 94 . Rockwell suggested that if he was denied a visa

\footnotetext{
Letter from T.H.E. Heyes to E. J. Bunting, 31 January 1961, A1209 1961/308, NAA (Canberra).

'George Lincoln Rockwell-American Nazi Party Application for a Visa', 13 February 1961, A1209 1961/308, NAA (Canberra).

'George Lincoln Rockwell-American Nazi Party Application for a Visa', 6 March 1961, A1209 1961/308, NAA (Canberra).

Cited in, Letter from C.C.F. Spry to Hon. Sir Garfield Harwick, April 1961, A6119 2306, NAA (Canberra).
} 
by the Australian government, he would seek help from the US State Department (New York Times, 31 January 1961), but this also did not eventuate and after a week of publicity, the ANWP announced that the plan had fallen through. Smith was quoted in the New York Times (6 February 1961) as saying, "Our invitation caused too much trouble and, if we had persisted in it, we would have antagonized the Government."

While the flurry of media attention had thrust Royce and Smith into the national spotlight, the ANWP had dissolved by the following year, with Smith moving to Tasmania before becoming the leader of the recently founded Australian National Socialist Party (ANSP) in 1964. As Smith (2020) has shown, the neo-Nazis in Australia continued to have contact with Rockwell and Colin Jordan in Britain, but there were no more attempts to bring far-right figures to Australia from these groups.

\section{Rockwell's Illegal Entry into Britain}

Between late 1961 and early 1962, Colin Jordan broke with John Bean's British National Party over whether the party would indulge in explicit National Socialism, as well as paramilitarism. In April 1962, Jordan founded the National Socialist Movement and sought to forge closer links with Rockwell's American Nazi Party, culminating in the organisation of a meeting to launch the World Union of National Socialists. Although Rockwell had previously tried to establish the World Union of Free Enterprise National Socialists, this joint endeavour between Rockwell and Jordan brought together neo-Nazis from North America, Britain and continental Europe in the Cotswolds in the south-west of England in August 1962 (Jackson 2019, pp. 280-81).

Jordan had previously organised similar events which were attended by European and North American delegates, including Robert Lyons from the National States Rights Party in the United States (Walker 1977, p. 36; Macklin 2020, p. 327), which had not been hindered by the Home Office's visa restrictions. According to Macklin (2020, p. 327), Rockwell had previously enquired about applying for a visa to visit Britain in 1961, but "[r]ealising that this would not be granted Rockwell (temporarily) abandoned his plans".

On 1 July 1962, the newly founded National Socialist Movement held a rally in Trafalgar Square, which descended into chaos as anti-fascist protestors clashed with the NSM and the police, ending, according to The Guardian (2 July 1962), "with 20 arrests, fights, bleeding faces, abuse and tears". In the wake of this, the authorities focused more on the far right, with a planned demonstration in the same place in a fortnight's time by Mosley's Union Movement banned. When Jordan announced the plan to bring international neo-Nazi figures to Britain for a private conference in the countryside and a public rally in Trafalgar Square in August, the Conservative home secretary, Henry Brooke, instructed immigration officers to refuse entry to "anyone who is known to be coming to attend a National Socialist world conference" (The Times, 2 August 1962, p. 10). At this time, citizens of the United States and several Western European countries did not need to obtain a visa before they left their own country and could obtain permission to enter at the port of entry.

The Times (2 August 1962) reported that members of the Jewish community met with the home secretary to encourage more to be done about "neo-Fascist groups". Internal correspondence between the home secretary and the prime minister shows that while Harold Macmillan believed that "the Nazi revival is being worked up by Left-wing people for political purposes", it was recognised that Jordan's proposed meeting and Rockwell's presence in the country had seen "a genuine and deep feeling of fear being aroused among the Jewish population" ${ }^{\prime 9}$. After stating that he thought that Macmillan may have been "underrating the political significance of these rows over neo-fascist meetings, and of the Government's handling of them", Brooke wrote:

9 Letter from Harold Macmillan to Henry Brooke, 9 August, 1962, PREM 11/3822, The National Archives (hereafter TNA); Letter from Henry Brooke to Harold Macmillan, 9 August 1962, PREM 11/3822, TNA. 
I am anxious to handle the situation in a way which not only will be seen to be reasonable, but also will command the confidence of Jews as well as the rest of the population, and will not turn the whole of the Jewish vote solidly against the Government ${ }^{10}$.

In response to Brooke, Macmillan acknowledged that "we must be careful of the special susceptibilities of the Jews, for which, after all, they have considerable historical justification", but also encouraged the home secretary not to "neglect the opportunities which this situation creates of improving the general security of the country"11. A previous letter by Macmillan to Brooke spells this out clearly: "What is important for us is always to link Fascists and Communists together. Communism is the real danger but we should, by linking the two together ..., do a useful thing in our own long-term interests"12.

This reflects the general attitude of the British authorities towards fascism in the post-war period, with communism seen as a greater threat and fascism predominantly seen as a problem with regards to public order.

With immigration officials given orders to refuse Rockwell entry to Britain, the American Nazi Party leader bypassed these controls by entering the country via Ireland. The British Nationality Act 1948 gave all British subjects (including from the Irish Free State) the right to enter, reside and work in the United Kingdom. When the Republic of Ireland was established in 1949, the Irish retained these rights even though they were, in the words of Kathleen Paul (1997) "neither subjects nor aliens". Even after the Commonwealth Immigrants Act 1962 put limits on migrants from the Commonwealth, Irish citizens were exempt from these controls. Before the outbreak of "the Troubles" in 1969, passage between Britain and the Republic of Ireland was, for the most part, not monitored, particularly via the Irish Sea. Although Irish ports were supposedly monitored "to prevent parties of West Indians from entering the United Kingdom" (Paul 1997, p. 109) after the 1962 Act, most "white" passengers were left to their own devices.

While Rockwell was whisked away to the WUNS conference in the Cotswolds, the British press got wind that he had evaded immigration controls and entered via Ireland. The Daily Mirror (7 August 1962) pronounced that a "glaring loophole in Britain's security defences had been exposed by the 'back-door' entry into this country of the world's top Nazi", further exclaiming "Rockwell apparently got into England quite simply and perhaps without subterfuge ... BECAUSE THERE IS NO IMMIGRATION CHECK BETWEEN IRELAND AND ENGLAND." The Times (7 August 1962) also editorialised on this, writing:

The fact that Mr. Rockwell seems to have found no difficulty in entering the country has thrown doubts on the effectiveness of the check on aliens, and Commonwealth immigrants, entering by way of Ireland. The Irish Republican authorities are understood to have made similar requirements to those made at British ports and airports when the Commonwealth Immigrants Act came into force.

It emerged that Rockwell had arrived in Ireland and been given permission to enter before Henry Brooke had given the order to British immigration officials to refuse entry (The Guardian, 8 August 1962).

Rockwell's presence in the country did arouse public anger and instances of disorder. When word got out that Rockwell was at a neo-Nazi camp in the Gloucestershire countryside, a number of protestors who objected to the Nazis descended from a nearby village and overran the campsite. Copsey (2007, p. 97) writes that "around 100 local villagers ... stormed the camp" and "[i]n a 20 min pitched battle, tents were flattened and one villager fired a shot that pierced the swastika on the flag

10 Letter from Henry Brooke to Harold Macmillan, 9 August 1962, PREM 11/3822, TNA.

11 Letter from Harold Macmillan to Henry Brooke, 10 August 1962, PREM 11/3822, TNA.

12 Letter from Harold Macmillan to Henry Brooke, 9 August 1962, PREM 11/3822, TNA. 
flying over the camp". Police eventually intervened, but by the time that they arrived, Rockwell had fled.

The home secretary issued a deportation order and Rockwell was apprehended by Special Branch officers in London as he attempted to approach the offices of a national newspaper in Holborn (Daily Telegraph, 9 August 1962) ${ }^{13}$. The Home Office stated that while "Mr Rockwell's admission to this country had not at the time of his arrival [into Ireland] been specifically prohibited", he made a false claim upon entry as he declared that "his intention was to spend a holiday there" (The Guardian, 8 August 1962) — not be the guest of honour at a neo-Nazi conference in England. Taken to London Airport with a police escort, Rockwell gave a Nazi salute as he boarded the plane. The Daily Telegraph (9 August 1962) reported that a State Department spokesperson in Washington remarked, "The British are perfectly free to throw him out", while the US Embassy in London admitted that they would not be "anxious to help" Rockwell pay for his flight home.

As Rockwell was being removed from the country, his entry via Ireland was held up by some as an example of the problems of Irish citizens being exempt from the Commonwealth Immigrants Act and the lack of border control between the two nations. After the Home Office acknowledged that there was only a customs check for people arriving in Britain from Ireland, "but no routine passport check or immigration control", an editorial in the Daily Mirror (7 August 1962) lamented that initial ban by Brooke was "meaningless". The newspaper exclaimed, "It now also looks as if a whole regiment of Nazis could sneak in by the back door from Ireland without being challenged by Britain". Another newspaper editorial, this time in The Guardian (8 August 1962), said that although "the Irish back door into Britain [for Rockwell] no longer looks quite so wide open as it did", it warned that the relationship between London and Dublin, which had allowed traffic between the two countries to remain largely unencumbered, might be strained "if it seemed that anyone-whether alien or Commonwealth — could get into Britain by entering Ireland as a tourist and then catching a plane or boat across the Irish Sea". The Irish Independent (8 August 1962) reported that Home Office officials "did not deny that the process of entry from Ireland could become the subject of some research" and "might even lead to overall immigration, as well as customs, inspection". However, it was not until the early 1970s, with the beginning of the Provisional Irish Republican Army's bombing campaign in England, that movement across the Irish Sea was more regularly monitored (Doody 2012).

In the following decade, the Rockwell case was referred to several times in Parliament in debates over immigration laws and regulations. A few months after Rockwell was deported, Section 1 of the Aliens Restriction (Amendment) Act 1919, which gave the home secretary the power to refuse entry to or deport any alien on reasonable grounds via the Aliens Order 1953, came up for annual continuance. The Labour MP Dingle Foot questioned the broad interpretation of the powers of the home secretary to deport anyone who was not "conducive to the public good" and wondered whether an appeals tribunal, similar to that existed in the United States, Canada and Australia, was required to hear cases of deportation (House of Commons, 28 November 1962, col. 418-19). Henry Brooke replied that even though Rockwell's entry was not conducive to the public good, "if we had to go through court proceedings, it would not have been possible for me to deal with Rockwell as I was able to deal with him", because he had not been charged or convicted of any particular offence (House of Commons, 28 November 1962, col. 435). Brooke suggested that any court proceedings would have only delayed Rockwell's inevitable deportation under the 1953 Order and that Parliament needed to consider whether a tribunal was needed to deliberate on immigration matters (House of Commons, 28 November 1962, col. 436). When Labour assumed office in 1964, they retained the immigration control system inherited from the Conservatives and when the Aliens Restrictions (Amendments) Act 1919 came up again for consideration for continuance, Lord Stonham from the Home Office used the

13 The New York Times (9 August 1962) named this newspaper as the Daily Mirror, which The Guardian suggested may have paid Rockwell and Jordan for access (8 August 1962). 
Rockwell case as a reason for the powers to refuse entry and deport, arguing that "the Government must have the right to decide who may enter the country and who should be excluded" (House of Lords, 6 December 1965, col. 12). This included those deemed "undesirable" as they "represent a threat to this country's security or whose activities are inimical to a freedom-loving society".

The Wilson government eventually drafted an Immigration Appeals Bill in 1969, which, at the same time, gave the home secretary the powers to deport Commonwealth migrants who breached their conditions of entry. In the parliamentary debates that followed, the Rockwell case was evoked again. The former home secretary, now Lord Brooke of Cumor, argued that if, at the time, Rockwell had been a Commonwealth citizen: "I am certain that his presence here advocating Nazi doctrines would have been no less unacceptable to public opinion, but there would have been no means of getting rid of him because he would be immune from deportation" (House of Lords, 27 March 1969, col. 1431).

Lord Brooke suggested that while the Labour government deliberated over the mechanisms for deporting Commonwealth citizens and the establishment of an appeals tribunal, they should have likewise deliberated "whether the long-standing power to deport an alien on the ground that his presence here is not conducive to the public good should not be extended to a Commonwealth citizen also". However, the Wilson government did not take this suggested amendment into consideration any further, with Lord Stonham stating that this proposal by Brooke was "undesirable" (House of Lords, 13 May 1969, col. 47).

This power was eventually included in the Immigration Act 1971, introduced by the incoming Conservative government, which also collapsed the distinction between Commonwealth and alien migrants into "patrial" (those with an ancestral link to the UK) and "non-patrial" (those who did not). While debating the Immigration Bill in the House of Lords, Brooke brought up the Rockwell case again, commending the fact that he was able to deport Rockwell swiftly because he was an alien and not a Commonwealth citizen (House of Lords, 24 June 1971, col. 1130). Claiming that popular opinion was behind him for this action, Brooke highlighted the supposed discrepancy between the laws in place to deal with undesirable aliens and undesirable Commonwealth subjects:

The point which occurred to me at that time was that I was able to get rid of him with the full support of public opinion because he happened to be American. Had he been Canadian, it would have been impossible to do anything. Yet there is no doubt whatever that public opinion would have been just as strong against this man whatever his nationality, because it was detestable to the British public, at any rate after this short interval of time since the war, to have people coming into this country and declaring what a splendid man Hitler was. (House of Lords, 22 July 1971, col. 1171)

This inconsistency was removed by the 1971 Act, with the proviso that it would be used sparingly against those from the Commonwealth deemed politically undesirable. Although there were several controversial cases of deportation for political or national security reasons during the 1970s and 1980s, these were of mainly non-Commonwealth citizens who were deported after lengthy court processes (such as the deportation of German left-wing activist Rudi Dutschke and US citizens Philip Agee and Mark Hosenball) $)^{14}$.

\section{Other Far-Right Figures}

George Lincoln Rockwell was not the only far-right figure from the United States that the British authorities sought to exclude from entering the country. In 1965, the West Midlands saw several anti-immigrant individuals seek to form a branch of the Ku Klux Klan (KKK). Webb (2014, p. 73) shows that the initiative to establish a KKK branch in Britain came after the formation of the Birmingham Immigrant Control Association in 1961 and "the election of Peter Griffiths as MP for Smethwick

14 For discussion of the Rudi Dutschke case, see: (Hepple 1971). For discussion of the Agee/Hosenball case, see: (Campbell 1979). 
following a blatant racist campaign three years later". News reached the United States and with this small meeting of people (a number being defectors from Jordan's NSM), the Imperial Wizard of the KKK, Robert Shelton, announced that he would seek to come to Britain (Webb 2014, pp. 74-75). The Daily Telegraph (12 June 1965) reported that news of Shelton's proposed visit "was received with a mixture of anger and anxiety" and Labour's Maurice Foley, who had ministerial responsibilities for immigrant integration, stated that "Mr. Shelton would soon learn that Birmingham, England, was very different from Birmingham, Alabama." Shelton's proposed visit was raised in Parliament and the Labour Home Secretary Frank Soskice proclaimed:

If Mr. Robert Shelton, or any other foreigner identified as being engaged in the activities of the $\mathrm{Ku}$ Klux Klan, arrives here he will be refused leave to land; and any foreign visitor found to be engaged in such activities during his stay in this country will be required to leave. (House of Commons, 15 June 1965, col. 240)

Despite this ban, Shelton suggested that he would defy this and still attempt to travel to the UK in the autumn of 1965 (Daily Telegraph, 16 June 1965), but this did not eventuate.

Australia was more lenient with far-right visitors to its shores. In 1960, the League of Empire Loyalists's A.K. Chesterton visited Australia and New Zealand after travelling from South Africa (LeCras 2020, pp. 109-10). According to New Times (11 March 1960), the publication of the Australian League of Rights (ALOR), Chesterton delivered speeches in Melbourne, Hobart, Adelaide and Sydney before making his way across the Tasman Sea. Despite the prime minister, Jewish groups and trade unions raising the issue of anti-Semitism at this time (The Age, 27-29 January 1960), Chesterton's visit and his links to the ALOR were not reported on in the national press, besides one article in the Jewish News (26 March 1960) (for which Chesterton sued for libel) ${ }^{15}$. The declassified ASIO file on Chesterton is very brief, but noted that he had previously addressed the branch of the League of Empire Loyalists that briefly existed in Adelaide in the late 1950s and early 1960s and notes that Chesterton has been labelled by others as a "fascist extremist"16. The Special Branch of the South Australian Police stated that there was intelligence that Chesterton would return in 1964 to settle the libel case against Jewish News in Melbourne ${ }^{17}$, but there is no record of another visit.

In 1968, it was reported in The Age (5 December 1968) that Oswald Mosley was looking to come to Australia to write about the country for The Times in London. Although this was not confirmed, it sparked a number of protests, particularly from the Jewish community and the RSL. The president of the Executive Council of Australian Jewry wrote to Billy Snedden, the minister for immigration, declaring, "We are confident that no decent Australian would like to see the marching jackboots of a Fascist leader defiling Australia's soil"18. The Canberra Times (26 December 1968) cited the national secretary of the RSL as saying that Mosley "would not be welcome in Australia" and because Mosley had been a "near life-long fascist", the RSL "would not like to see him come here".

In a memo from the director general of ASIO, Charles Spry, to the minister for immigration, it was noted that Mosley had been overtaken by other far-right groups in Britain (for example, Colin Jordan's National Socialist Movement and the National Front), but Mosley was "still a potential focus for Right Wing extremists", adding "though he may not actually organise violent demonstrations, he seems never to have been active in restraining his more violent supporters"19. An earlier letter from the director general to the prime minister's office noted that a visit by Mosley would bring protest from "a variety of sources in the community", such as "Jewish, Returned Soldiers, Civil Liberties groups, Anti-Fascists, the Communist Parties, those vocally supporting racial integration, those opposed to

15 South Australian Police (SAPOL) Special Branch note, 19 August 1964, A6126 1424, NAA (Canberra).

16 SAPOL Special Branch note, 19 August 1964, A6126 1424, NAA (Canberra). For further information on the League of Empire Loyalists in Australia, see: (Smith 2018), p. 74.

17 SAPOL Special Branch note, 19 August 1964, A6126 1424, NAA (Canberra).

18 Letter from Gerald Y. Falk to B.M. Snedden, 27 December 1968, A6980 S202516, NAA (Canberra).

19 Letter from Director General of ASIO to Department of Immigration, 3 February 1969, A6980 S202516, NAA (Canberra). 
South African and Rhodesian governmental policies and those attempting to obtain a passport for Wilfred BURCHETT"20. Spry also warned of "pro-Nazi groups or individuals" demonstrating in support of Mosley, as well as the possibility that "individuals or even small groups of persons could take an active 'anti-MOSLEY' attitude"21. Despite the potential for public disorder, Spry concluded:

I do not consider MOSLEY to be a security risk for admission into Australia. However, a visit by him would entail some coverage by my Organisation, thereby engaging staff who would need to be detached from other matters bearing more directly on the internal security of Australia ${ }^{22}$.

Snedden confirmed to the press that Mosley would not be banned if he sought to visit Australia, labelling him a "spent force" (Canberra Times, 30 December 1968). In the end, Mosley decided not to follow through with his proposed visit, telling journalists that when his visit was mentioned in the press, "it was stated that I must first ask permission of some official" (The Australian, 4 January 1969). "This ... " Mosley stated, "I refused to do".

\section{Conclusions}

Even in the post-World War II period, the British and Australian authorities were reluctant to ban domestic fascist or neo-Nazi groups. In a draft Foreign and Commonwealth Office circular, the British government argued that the "domestic activities of these organisations are more difficult to control" and "could hardly, in peacetime, be curtailed or banned for their own sakes by Her Majesty's Government without seriously damaging the essential democratic rights of free speech and free assembly"23. The circular continued that although there was "general distaste" for "these neo-Fascist bodies", it was the opinion of the government that "there is little in a mature democracy that can or should be done to interfere with them officially, so long as public order is maintained"24. The Public Order Act 1936 had been implemented to curb the activities of the British Union of Fascists in the 1930s and had been cited by successive governments as the mechanism for controlling the far right in Britain throughout the post-war era.

After the successor of the Australian Nationalist Workers Party, the Australian National Socialist Party, held a small public gathering in New South Wales, the Commonwealth Police Force advised the Attorney-General's Department that the Commonwealth did not have similar laws to the Public Order Act 1936 in Britain, which banned processions of paramilitary uniforms and that the failure of the Menzies government to ban the Communist Party of Australia in 1950-51 "establishes that there can be no Commonwealth power to ban the party"25. It also commented that any proposed legislation similar to the Public Order Act would have to be enacted at state, rather than Commonwealth, level ${ }^{26}$.

In the late 1950s and early 1960s, both the British and Australian governments allowed these neo-Nazi groups to legally exist, but put them under surveillance by the security services and used public order legislation to curb their public presence, while heavily policing anti-fascist protestors at the same time. This concern about public order also shaped both governments' approaches towards far-right figures visiting from outside the country. George Lincoln Rockwell's notoriety for indulging in provocative publicity stunts and encouraging public protest against these stunts was cited by both governments as a reason to deny Rockwell entry in the early 1960s. Rockwell's propensity for

20 Letter from C.C.F. Spry to Prime Minister's Department, 25 December 1968, A6980 S202516, NAA (Canberra). Wilfred Burchett was a communist journalist who had had his passport revoked in 1955 and only reissued by the Whitlam government in 1972 (Heenan 2006).

21 Letter from C.C.F. Spry to Prime Minister's Department, 25 December, 1968, A6980 S202516, NAA (Canberra).

22 Letter from Director General of ASIO to Department of Immigration, 3 February, 1969, A6980 S202516, NAA (Canberra).

23 FCO Circular, 'Neo-Fascism in Great Britain', August 1962, FCO 168/689. The National Archives (London).

24 FCO Circular, 'Neo-Fascism in Great Britain', August 1962, FCO 168/689. The National Archives (London).

25 Letter from John Ballard to Mr Edmunds, 18 June 1964, A432 1963-2409 PART 1, NAA (Canberra).

26 Letter from John Ballard to Mr Edmunds, 18 June 1964, A432 1963-2409 PART 1, NAA (Canberra). 
advocating racial violence was a large factor in both the ASIO recommendation that he be denied entry in Australia and Henry Brooke's push for immigration officials to exclude him from Britain. Coming a month after the National Socialist Movement rally in Trafalgar Square and the subsequent ban of political events in that central London space, Rockwell's presence in Britain was seen as deliberate antagonism (especially of the Jewish community) and Brooke also used this to justify his decision to (albeit unsuccessfully) ban the American Nazi Party leader. The association of the Ku Klux Klan with racial violence and public displays of racism (such as cross burning) also led to Labour Home Secretary Frank Soskice excluding the KKK Imperial Wizard Robert Shelton from Britain in 1965.

Comparison with the little controversy surrounding the visit by the League of Empire Loyalists' A.K. Chesterton in 1960 and the reluctance of the Gorton government to refuse Mosley a visa in 1968-69 highlights that it was Rockwell's public advocacy of racial violence and possibility of public disorder that led the Menzies government to exclude him in 1961. The Australian government was very concerned about not importing "racial strife" (as was seen in the United States) into the country at this time and refusing entry to Rockwell reinforced the idea that conflict over issues of race and racism was something that happened outside of Australia, not within it.

Both the Australian and British governments used the border control system to keep back political ideologies, groups and individuals which they saw as harmful to the public and to national security. While scholars have looked at how this was used against left-wing, anti-colonial and other progressive activists throughout the twentieth century, this article has shown that it was also utilised against some individuals on the far right. With American Nazi Party leader George Lincoln Rockwell, both the home secretary in Britain and the minister for immigration in Australia sought to refuse entry on the grounds that Rockwell's presence in the country was not conducive to the public good, with the possibility of public disorder and advocacy of racial violence-even though Rockwell was invited in both instances by local neo-Nazi groups that were allowed to legally operate. These bans relied on mechanisms that complemented immigration control legislation and on the discretion of the home secretary or the minister for immigration to proactively intervene before the applicant arrived at the port of entry. This meant that public campaigns against proposed foreign visitors, such as Rockwell, were instrumental in pressuring the government to take the line of banning far-right individuals from entering, even though it also relied on the already existing functions of a racially discriminatory border control system.

Funding: This research was funded by the Australian Research Council as part of the ARC Discovery Project 'Managing Migrants and Border Control in Britain and Australia, 1901-1981' (ARC DP 180102200).

Conflicts of Interest: The author declares no conflict of interest.

\section{References}

Aarons, Mark. 1989. Sanctuary: Nazi Fugitives in Australia. Port Melbourne: William Heinemann Australia.

Brückenhaus, Daniel. 2017. Policing Transnational Protest: Liberal Imperialism and the Surveillance of Anticolonialists in Europe, 1905-1945. Oxford: Oxford University Press.

Campbell, Duncan. 1979. Official Secrecy and British Libertarianism. Socialist Register 16: 75-88.

Cesarani, David. 1992. Justice Delayed: How Britain Became a Refuge for Nazi War Criminals. London: Heinemann. Copsey, Nigel. 2007. Anti-Fascism in Britain. London: Routledge.

Deery, Phillip. 2005. “Dear Mr Brown": Migrants, Security and the Cold War. History Australia 2: 40.1-40.12. [CrossRef]

Doody, Josephine. 2012. Creating suspect communities: Exploring the use of exclusion orders in Northern Ireland. Behavioral Sciences of Terrorism and Political Aggression 4: 77-98. [CrossRef]

Finnane, Mark, and Andy Kaladelfos. 2019. Australia's Long History of Immigration, Policing and the Criminal Law. In Crimmigation in Australia: Law, Politics and Society. Edited by Peter Billings. Singapore: Springer, pp. 19-37.

Freckelton, Alan. 2015. Administrative Decision-Making in Australian Migration Law. Canberra: ANU Press. 
Harcourt, David. 1972. Everyone Wants to be Fuehrer: National Socialism in Australia and New Zealand. Cremorne: Angus \& Robertson.

Heenan, Tom. 2006. From Traveller to Traitor: The Life of Wilfred Burchett. Melbourne: Melbourne University Press. Henderson, Peter. 2005. Frank Browne and the Neo-Nazis. Labour History 89: 73-86. [CrossRef]

Hepple, Bob. 1971. Aliens and Administrative Justice: The Dutschke Case. Modern Law Review 34: 501-19. [CrossRef]

Jackson, Paul. 2018. Colin Jordan and Britain's Neo-Nazi Movement. London: Bloomsbury.

Jackson, Paul. 2019. Dreaming of a National Socialist World: The World Union of National Socialists (WUNS) and the Recurring Vision of Transnational Neo-Nazism. Fascism 8: 275-306. [CrossRef]

LeCras, Luke. 2020. A.K. Chesterton and the Evolution of Britain's Extreme Right, 1933-1973. London: Routledge.

Macintyre, Stuart. 1999. The Reds: The Communist Party of Australia from Origins to Illegality. St Leonards: Allen \& Unwin.

Macklin, Graham. 2020. Failed Führers: A History of Britain's Extreme Right. London: Routledge.

Moore, Andrew. 1995. The Right Road: A History of Right-Wing Politics in Australia. Melbourne: Oxford University Press.

Nicholls, Glenn. 2007. Deported: A History of Forced Departures from Australia. Sydney: UNSW Press.

Paul, Kathleen. 1997. Whitewashing Britain: Race and Citizenship in the Postwar Era. Ithaca: Cornell University Press.

Persian, Jayne. 2017. Beautiful Balts: From Displaced Persons to New Australians. Sydney: NewSouth.

Piccini, Jon. 2016. Transnational Protest, Australia and the 1960s. Houndmills: Palgrave Macmillan.

Renton, David. 2000. Fascism, Anti-Fascism and the State in the 1940s. Houndmills: Palgrave Macmillan.

Simonelli, Frederick J. 1999. American Fuehrer: George Lincoln Rockwell and the American Nazi Party. Urbana: University of Illinois Press.

Smith, Evan. 2018. Exporting Fascism across the Commonwealth: The Case of the National Front of Australia. In 'Tomorrow Belongs to Us': The British Far Right Since 1967. Edited by Nigel Copsey and Matthew Worley. London: Routledge, pp. 69-89.

Smith, Evan. 2020. White Australia Alone? The International Links of the Australian Far Right in the Cold War Era. In From Apartheid to Trump: Towards a Global History of White Nationalism. Edited by Daniel Geary, Camilla Schofield and Jennifer Sutton. Manchester: Manchester University Press, pp. 231-61.

Thurlow, Richard. 1998. Fascism in Britain: A History, 1918-1998. London: IB Tauris.

Ullrich, Wes. 2011. Preventing "Peace": The British Government and the Second World Peace Congress. Cold War History 11: 341-62. [CrossRef]

Walker, Martin. 1977. The National Front. Glasgow: Fontana.

Webb, Clive. 2014. Jim Crow and Union Jack: Southern Segregationists and the British Far Right. In The Post-War Anglo-American Far Right: A Special Relationship of Hate. Edited by Paul Jackson and Anton Shekhovtsov. Houndmills: Palgrave Macmillan, pp. 67-83.

(C) 2020 by the author. Licensee MDPI, Basel, Switzerland. This article is an open access article distributed under the terms and conditions of the Creative Commons Attribution (CC BY) license (http://creativecommons.org/licenses/by/4.0/). 